\title{
CORRUPTION FROM FRAUD THEORY PERSPECTIVE
}

\author{
Efrizal Syofyan $^{1 *}$, Dovi Septiari ${ }^{2}$, Emi Muliyanti $^{3}$, and Riski Hernando ${ }^{4}$ \\ ${ }^{* 1}$ Universitas Negeri Padang \\ Faculty of Economics \\ Jl. Prof. Dr. Hamka, Air Tawar, Padang 25171, Indonesia \\ E-mail: efrizal_syofyan@fe.unp.ac.id \\ ${ }^{2}$ Universitas Negeri Padang \\ Faculty of Economics \\ J1. Prof. Dr. Hamka, Air Tawar, Padang 25171, Indonesia \\ E-mail: dovi.septiari@fe.unp.ac.id \\ ${ }^{3}$ Universitas Negeri Padang \\ Faculty of Economics \\ Jl. Prof. Dr. Hamka, Air Tawar, Padang 25171, Indonesia \\ E-mail: muliyantiemi1@gmail.com \\ ${ }^{4}$ Universitas Jambi \\ Faculty of Economics and Business \\ 1. Jambi - Muara Bulian No.KM. 15, Mendalo Darat, Jambi 36361, indonesia \\ E-mail: jurnalintegrasi@yahoo.com
}

\begin{abstract}
Abstrak
Penelitian ini bertujuan untuk menganalisis fenomena korupsi dari perspektif teori fraud. Khususnya, kami menguji efek keserakahan, peluang, kebutuhan, dan kapabilitas terhadap prilaku korupsi. Sampel penelitian ini adalah 31 narapidana korup di Lapas II-A Padang, Indonesia. Metode sampling yang digunakan dalam penelitian ini adalah full sampling_Hasil penelitian menunjukkan bahwa keserakahan dan kesempatan mempengaruhi korupsi. Tapi kami menemukan bahwa kebutuhan dan kapabilitas tidak mempengaruhi korupsi. Temuan ini memberikan implikasi terhadap perkembangan pengetahuan bahwa teori fraud dapat menjelaskan fenomena korupsi. Studi ini juga memiliki kontribusi bagi regulator dan pemerintah.
\end{abstract}

Kata kunci: Korupsi, Keserakahan, Kesempatan, Kebutuhan, Kapabilitas

\begin{abstract}
This study aims to analyze the corruption phenomena from a fraud theory perspective. Primarily, we examine the effect of greed, opportunity, need, and Capability on corruption behavior. The sample of this study was 31 corrupt inmates in the Padang II-A prison in Indonesia. The results showed that greed and opportunity affect corruption. But we found that need and Capability did not affect the corruption. This finding implies the body of knowledge that fraud theory may explain the corruption phenomena. This study also has a contribution to the regulators and government.
\end{abstract}

\section{Keywords: Corruption, Greed, Opportunity, Need, Capability}




\section{Introduction}

Corruption is caused by several factors, such as internal and external, or individual and structural [1]. In the era of globalization, corruption has become a criminal phenomenon concerning multilateral and international relations. Transparency International released the Corruption Perception Index (CPI) of 11 countries in Southeast Asia. Singapore, and Brunei Darussalam had a CPI above 50. Even Singapore had a CPI of 84 , meaning that Singapore's country was the cleanest country of corruption in Southeast Asia. At the same time, Indonesia has ranked the sixth most corrupt country, with CPI is 37.

Corruption occurs in all aspects of life and high state institutions such as the police, prosecutors, courts, parliament, political parties, and state officials involved in corruption scandals. The perpetrators of the criminal act of corruption are intellectuals who, before committing their actions, had already made preparations and calculations carefully so that they can manipulate the law so that the crime goes undetected. In government area, the habit of misusing government officials' financial budgets can occur at all government systems levels [2]. Budget abuse committed by government officials causing budget leaks. Example reports use of a fictitious airline ticket amount to the travel budget agencies that are not appropriate or fictitious conduct or training on fictitious technical guidance or internal corruption procurement of goods and services [3], [4]. According to World Bank institutions, total money worth more than the US \$ 1 trillion has been used to bribe each year, while the total loss due to corruption in developing countries has reached nearly US $\$ 80$ billion per year.

Corrupt practices in Indonesian government institutions are spread in the executive, legislative, and judiciary institutions based on greed, opportunity, need and low punishment and culture [2], [5], [6]. Indonesia Corruption Watch (ICW) stated that several agencies are prone to be corruption, including agencies that deal directly with public services. Such as education, health, and transportation, as well as agencies that have large budgets, so they are prone to fraud or abuse of authority. From 2006-2015 there were five policemen caught in corruption cases. The Corruption Eradication Commission even arrested 75 Regional Heads and 144 legislative members from 2004 to 2017. Actually, the Indonesia government implement the systems to reduce this phenomena, but this has no effect [7].

According to GONE theory, there is four factors that influence someone to commit fraud: greed, need, opportunity, and exposure. Someone will commit corruption because humans are greedy creatures and are never satisfied with what they have [8]. Opportunity encourages someone who initially does not desire to commit fraud, but because of the chance, someone can commit fraud [8]. Behavior, an individual, begins with a need, then that need gives rise to an impulse, which if this urge is urgent, someone will do cheating behavior. Finally, Abilities or Capability will make someone cheating when there are people who have the right abilities. Meanwhile, opportunity and capability relating to corruption victims, namely organizations, communities whose interests are harmed.

This study wants to test the influence of greed, opportunity, and need based on the results of [9] by adding Capability factors. Some researchers have researched the aspects above, but there are still inconsistencies in the study results. Also, it can be important to see the relationship between GONE theory and fraud like Corruption in developing country like Indonesia. Our study also unique because we see the effect on real sample who involve with corruption. It will drive new knowledge about this theory. Based on the above, the research problem can be formulated as "Does greed, opportunity, need and Capability influence corruption?”.

\section{Literature Review}

\subsection{Fraud}

Fraud is an all-encompassing activity in various ways that are done cleverly by fictitiously to take a benefit 
from the other parties [10], [11]. Most fraud cases happen within organizations rather than in external dealings [12]. No definite and invariable rule can be laid down as a general proposition in defining fraud, as it includes surprises, trickery, cunning, and unfair ways by which another is cheated [11]. The only boundaries are those who limit human experience [11]. In particular, fraud can be intentional, lying, and committing this cheating as the opposite of the truth, justice, and equality. Fraud is carried out by forcing others to act against their best interests. Fraud scheme called the fraud tree.

The first form of the fraud called corruption. Corruption is employee fraud by abusing his company's influence by violating personal duties or his superiors' duties to get unique benefits directly. Corruption can occur in the public sector. [13] defines corruption as the behavior of public officials who deviate from accepted norms, serve personal purposes. Fundamental human values are a theory that can explain corrupt behavior, such as; power, achievement, hedonism, self-direction, security, stimulation, conformity, tradition, benevolence, and universalism [14]. There are forms of corrupt behavior including; financial loss state, bribery, deep embezzlement position, extortion, fraudulent acts, conflicts of interest in procurement and gratification. The corruption process can happen in a manner cryptic, slippery, and very cunning. A person's motive for corruption is to gain material benefits and improve the status, image, friendships, romance, and create others who are fascinated, impressed, and impressionable [15].

In the business context, fraud can appear in form of assets misappropriate [16]. Misappropriation of assets straightforward to detect because it is physical and can be counted. It occurs when an employee misappropriates the company's support for individual gain. Process misappropriation of assets carried out only uses assets and resources for undesired purposes. This model's fraud includes theft, embezzlement, and cash skimming [16]. Taking or stealing company assets is also included in this scheme.
The last form of fraud in fraud threes are fraudulent financial statement. It form have occurred over the past few years and are frequent [17], [18]. Top managers or company executives carry out fraudulent financial statements to conceal the actual financial condition by conducting financial statement fraud. The company's financial performance looks good in front of users of financial statements or known as window dressing. Fraudulent financial statements are caused by reckless behavior, whether through deliberate action or negligence, which results in material misleading financial statements [16]. The presentation of financial statements carried out inaccurately [16]. Fraudulent financial reporting will significantly impact the organization and public trust in the capital market [16].

\subsection{Fraud Theory}

The first fraud theory namely fraud triangle. According to this theory, there are reasons for an individual to commit fraud, namely by the presence of pressure, opportunity, and rationalization [10], [19]-[27]. These three factors influence each other to the same degree [28]. Support for the fraud triangle arises from professional auditors and standard setters who express that an investigator analyzing a financial report will measure the pressure (as in increased revenue or excessively high net income), resulting in fraud [29]. Pressure is the first factor that drives someone to commit fraud, such as corruption [27], [30]. Pressure is divided into financial pressure and non-financial pressure. Financial pressure is the most pressure experienced by someone than non-financial pressure [30]. In general, there has to be more than a financial incentive for white-collar crime to occur [28]. Meanwhile, [11] state that pressures can split into four groups: financial pressures such as greed, excessive living standards, and the number of bills or debts. Opportunities occur because of the internal control system's weakness, which is not maximal supervisory management, inadequate procedures, and opportunities to have control [27]. While, rationalization is the dominant factor where people take fraudulent action when the culprit is looking for justification for what they did; and feel what they are doing right without 
violating applicable legal rules [27].

The Fraud Triangle is a fundamental basis for developing and categorizing several international auditing standards [28]. Rationalization is justification for wrong actions committed is something reasonable, morally acceptable [30]. Some examples of rationalization are (1) the organization owes me; (2) I only borrow and will pay it back; (3) no party has been injured or injured; (4) I have more rights; (5) this action is for a good cause; (6) I must get wealth like everyone else; (7) the company does not prohibit this; (8) this is not a serious matter; (9) internal control is weak; (10) I want to improve my standard of living; (11) I modeled my boss or colleague; (12) I have done a lot of good to the company; (13) I only take a little from the company [31].

The second theory know as fraud diamond theory, introdeced by [32]. There are four elements that influence a person to commit fraud, namely pressure, opportunity, rationalization and capability [32]. Fraud diamond theory explains several indicators that trigger people to commit fraud, including challenges to defeat the system, for the good of the organization, weaknesses of the board of directors, inadequate internal control, the ability to obscure fraud, lack of controls to prevent fraudulent behavior, lack of access to information and lack of audit trail [7].

Last, [8] put forward a theory about fraud called "GONE Theory." The GONE view states that four factors encourage someone to commit fraud, namely Greed, Opportunity, Need, and Exposures. The Greed and Need factors relate to the individual perpetrators of the fraud. In contrast, the Opportunity and Exposure factors relate to victims of acts of fraud that occur in organizations, agencies, the people who suffer losses. Compare with Froud Triangle Theory, the GONE theory puts forward the exposure factor, which has been further improved in theory, and combined with the increasingly complex status of my country's financial fraud [33].

\subsection{Hypotheses Development}

Greed or greedy is related to greedy behavior potentially present in every human being [8]. Greed is an immoral act by corruptors who are never satisfied with their wealth. Greed is one of the factors driving someone to commit cheating. Someone will commit fraud because humans have greedy nature, never feel satisfied with what they already have, and are not happy with what is obtained [8]. If a person's level of greed is high, there is a tendency for someone to cheating. The individual's greedy nature is caused by the absence of gratitude for God, which have been given to him.

Greed is related to the greedy behavior found in everyone. Someone will commit corruption because humans are greed creatures and are never satisfied with what they have. Greed is the dominant factor for someone to be corrupt. Greed has a relationship with a person's morals. Individuals with a low level of morality will be greedier than individuals with high character [24]. Greed arises from financial pressure [34] and non-financial pressure [35] experienced by someone. Research by [2] prove the effect of greed on cheating. Our first hypothesis state that:

\section{H1: Greed have positive influence on Corruption} behavior

Opportunity is a situation that opens opportunities to allow fraud to occur [8]. Opportunities will arise when the control system is weak, and individuals will commit fraud if there is an opportunity. Opportunity is related to the opportunities in a situation so that the actors take the opportunity to engage in corruption. Opportunities lead to fraudulent acts caused by the quality of the system's poor internal control. It becomes an opportunity for employees to commit fraud when he works. Opportunity is an essential component of fraudulent behavior because if a fraud perpetrator does not have the opportunity to act, then fraud is impossible to do. Opportunity is considered a trigger factor for someone to commit fraud because if a fraudster does not have the opportunity to do so, fraud will not occur. Opportunity creating situation or condition that someone can commit fraud. Opportunity 
encourages someone who initially does not desire to commit fraud, but because of the opportunity, someone can commit fraud. Opportunity is one factor causing a person to commit corruption because of his weak oversight due to vulnerable organization and abuse of authority. Opportunities are an important part of any corruption because they are considered a trigger factor for fraud [36].

\section{H2: Opportunity have positive influence on Corruption behavior}

Need is related to individuals' factors to support a useful life [8]. Need is an internal factor that inherent in a person taking deviant actions [8] or as a mentality that was never feeling enough, constantly feeling to meet a need that will never be enough. Everyone has more needs to be a driving force for fraud. To meet these needs, people will do anything to meet their needs even though they have to cheat [8]. In line with some previous research that behavior an individual begins with the condition that needs further gives rise to an impulse, someone will do cheating behavior if this urge is urgent. Needs are associated with factors needed by humans to support their lives. Humans have a consumptive nature and needs that never end. Behavior, an individual, begins with a need, then that need gives rise to an impulse, which if this urge is urgent, someone will do cheating behavior.

\section{H3: Need have positive influence on Corruption behavior}

[8] state that exposure or disclosure is a factor related to an organization being a fraud victim. Exposure is related to the legal system that does not directly affect the perpetrators [2]. Exposure or disclosure is associated with the perpetrator of fraud's actions or consequences if the perpetrator is found to be cheating [8]. The fraud disclosure does not guarantee that the fraud will not be repeated either by the same perpetrator or by other actors [2], [8]. Therefore, every perpetrator of fraud should be subject to severe sanctions if his actions are exposed. When a company has a habit of giving forgiveness (without giving a warning letter and punishment) against employees who are proven to have cheated or helped fraud, then the auditor's perception of fraud in the company just got stronger. [32] states that other factors encourage someone to commit fraud, namely capability or ability. Personal traits and abilities that play a major role in whether fraud may actually occur even with the presence of the other three elements in fraud triangle [32]. Many frauds, especially some of the multibillion-dollar ones, would not have occurred without the right person with the right capabilities in place [32].

\section{H4: Capability have positive influence on Corruption} behavior

\section{Methodology}

This research is quantitative research to test a theory and shows the relationship Greedy, Opportunity, Need, and Capability on Corruption. This study's primary data through questioner was distributed to the corrupt inmate at Padang II A Prison directly. The number of samples is 35 , that quite small because there is difficult to get permission and send a survey to the prisoner.

The research instrument's design was carried out using a questionnaire distributed to respondents to obtain data containing a set of written questions. The questionnaires send to respondents divided into several pages that represent the existing variables. The questions attached to this questionnaire will define each predefined indicator variable. The variable measurement itself will be carried out with a 5-Likert scale. The steps taken in making the questionnaire are to determine the variable indicators, then each of them is described again become question items. The questionnaire used in this research is a closed form, where the answer to the questions asked has been provided. The respondent chooses one of the alternative answers in the form of positive and negative questions.

The validity of this research instrument is tested to see whether the instrument is valid or not. Validity testing can use the product-moment correlation formula. As for the criteria in the test, if $r$ count $\geq r$ tab (0.361) means the instrument is valid or $\mathrm{r}$ count $<\mathrm{r}$ tab $(0.361)$ 
means the instrument is invalid.

TABLE 1

VALIDITY TEST

\begin{tabular}{|c|c|c|c|}
\hline Items & $\begin{array}{c}\text { Corrected Item } \\
\text { - Total } \\
\text { Correlation }\end{array}$ & $\begin{array}{l}\text { Performance } \\
\text { Standard }\end{array}$ & Results \\
\hline Y1.1 & 0.808 & 0.300 & Valid \\
\hline Y1.2 & 0.406 & 0.300 & Valid \\
\hline Y1.3 & 0.839 & 0.300 & Valid \\
\hline Y1.4 & 0.723 & 0.300 & Valid \\
\hline Y1.5 & 0.536 & 0.300 & Valid \\
\hline Y1.6 & 0.784 & 0.300 & Valid \\
\hline X1.1 & 0.849 & 0.300 & Valid \\
\hline $\mathrm{X} 1.2$ & 0.432 & 0.300 & Valid \\
\hline $\mathrm{X} 1.3$ & 0.682 & 0.300 & Valid \\
\hline X1.4 & 0.763 & 0.300 & Valid \\
\hline X1.5 & 0.463 & 0.300 & Valid \\
\hline X1.6 & 0.862 & 0.300 & Valid \\
\hline X2.1 & 0.451 & 0.300 & Valid \\
\hline $\mathrm{X} 2.2$ & 0.791 & 0.300 & Valid \\
\hline X2.3 & 0.822 & 0.300 & Valid \\
\hline X2.4 & 0.555 & 0.300 & Valid \\
\hline $\mathrm{X} 2.5$ & 0.550 & 0.300 & Valid \\
\hline X2.6 & 0.717 & 0.300 & Valid \\
\hline X3.1 & 0.869 & 0.300 & Valid \\
\hline X3.2 & 0.808 & 0.300 & Valid \\
\hline X3.3 & 0.494 & 0.300 & Valid \\
\hline X3.4 & 0.650 & 0.300 & Valid \\
\hline X3.5 & 0.717 & 0.300 & Valid \\
\hline X3.6 & 0.403 & 0.300 & Valid \\
\hline X4.1 & 0.502 & 0.300 & Valid \\
\hline $\mathrm{X} 4.2$ & 0.802 & 0.300 & Valid \\
\hline $\mathrm{X} 4.3$ & 0.588 & 0.300 & Valid \\
\hline X4.4 & 0.453 & 0.300 & Valid \\
\hline X4.5 & 0.792 & 0.300 & Valid \\
\hline X4.6 & 0.856 & 0.300 & Valid \\
\hline
\end{tabular}

Then, we also test the instrument's reliability. The question item is said to be reliable when someone's answer to a question is consistent. In this research, the respondent's answer is in the form of a scale. We used the Cronbach alpha method for this purpose. With the alpha $\geq \mathrm{r}$ table $(0.70)$, it means that it is reliable. And if alpha $<\mathrm{r}$ table $(0.70)$, it means it is not reliable.

Validity testing in this study was conducted to show the level of validity of an instrument. The following shows the results of validity testing using the product moment correlation. Based on the validity test, it is shown that all items of each variable of Corruption Crime have a Corrected item-total Correlation value $\geqslant$ of 0.30 for each variable. It can interpret that all items in the indicator variable Corruption Crime are declared valid as well as that all things of each variable, Greedy (X1), Opportunity (X2), Need (X3) and Capability (X4), have a value Corrected item-total Correlation $\geqslant 0.30$. Thus, it can interpret that all items in the indicator variables are Greedy, Opportunity, Need, and Capability to have met the validity test.

The next step is to test the reliability using the Cronbach alpha $(\alpha)$ statistical test with the rule of thumb that must be greater than 0.70 (> 0.70). The following shows the results of reliability testing as in the table below.

TABLE 2

RELIABILITY TEST

\begin{tabular}{|c|c|c|c|l|}
\hline Variable & $\begin{array}{c}\text { Reliability } \\
\text { Coefficients }\end{array}$ & $\begin{array}{c}\text { Cronbach } \\
\text { Alpha }\end{array}$ & $\begin{array}{c}\text { Cronbach } \\
\text { Alpha } \\
\text { Standard }\end{array}$ & Results \\
\hline $\begin{array}{c}\text { Corruption } \\
\text { Crime }\end{array}$ & 6 items & 0.769 & 0.700 & Reliable \\
\hline Greed & 6 items & 0.753 & 0.700 & Reliable \\
\hline Opportunity & 6 items & 0.716 & 0.700 & Reliable \\
\hline Need & 6 items & 0.744 & 0.700 & Reliable \\
\hline Capability & 6 items & 0.758 & 0.700 & Reliable \\
\hline
\end{tabular}

We used multiple linear regression as the main analysis statistical tool used in this research. It is used to prove the relationship among variables. There are four independent variables and one dependent variable. The regression equation in this study is as follows: ${ }_{1} \mathrm{Gr}+$ $\beta_{2} \mathrm{Op}+\beta_{3} \mathrm{Ne}+\beta_{4} \mathrm{Ca}+e$

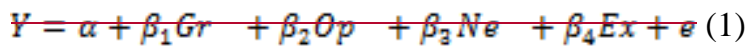

Description:

$\mathrm{Y}=$ Corruption 


$$
\begin{array}{ll}
\alpha & =\text { Constanta } \\
\beta 1-4 & =\text { Beta } \\
\mathrm{Gr} & =\text { Greed } \\
\mathrm{Op} & =\text { Opportunity } \\
\mathrm{Ne} & =\text { Need } \\
\mathrm{Ca} & =\text { Capability } \\
\mathrm{e} & =\text { Error }
\end{array}
$$

\section{Results and Discussion}

The distribution of respondents answers describes the frequency and distribution of respondents' responses in the questionnaire. Table 1 summarizes the distribution of the respondents' answers for each of the questions in the questionnaire.

Based on table 3, it can be seen that, for the variable of corruption, most respondents, $67 \%$, stated strongly agree, followed by $33 \%$ who said agree. These results mean that most respondents consider that corruption is high because of a lack of internal control.

For the variable of greed, the respondents are divided into three categories. $28 \%$ of respondents strongly agreed, $66 \%$ agreed, and $6 \%$ neutral. These results may reflect that $28 \%$ of respondents feel that the compensation is appropriate, $66 \%$ entirely appropriate, and $6 \%$ neutral. Therefore, in general, respondents consider the appropriateness of compensation, with an average value of 4,23 (scale 1-5). For the variable of opportunity, the respondents are divided into two equal categories. $48 \%$ of respondents strongly agreed, and $45 \%$ of respondents agreed. It means that most respondents consider that the internal control system is not effective, with an average value of 4,49 (scale 1-5).

TABLE 3

DISTRIBUTION OF RESPONDENT'S ANSWERS

\begin{tabular}{ccccccc} 
Variable & \multicolumn{5}{c}{ Percentage of Respondent's } & $\begin{array}{c}\text { Average } \\
\text { Answers }\end{array}$ \\
& $\mathbf{1}$ & $\mathbf{2}$ & $\mathbf{3}$ & $\mathbf{4}$ & $\mathbf{5}$ & \\
\hline Corruption & 0 & 0 & 0 & 20 & 11 & 4,35 \\
Greed & 0 & 0 & 2 & 19 & 10 & 4,23 \\
Opportunity & 0 & 0 & 0 & 15 & 16 & 4,49 \\
Need & 0 & 0 & 2 & 16 & 13 & 4,38 \\
& 0 & 0 & 2 & 17 & 12 & 4,32 \\
\hline
\end{tabular}

For the variable of need, the respondents are divided into three categories. $42 \%$ of respondents strongly agreed, 52\% agreed, and $6 \%$ neutral. It means that most respondents consider that they must fulfill their needs, with an average value of 4.38 (scale 1-5). $39 \%$ of respondents strongly agreed with the variable Capability, 55\% agreed, and 6\% neutral. It means Capability helps them corrupt.

Multiple linear regression analysis models are used to determine the effect of greed, opportunity, need, and corruption capability. A multiple linear regression model can be used in this research based on the classical assumption test results. Table 4 shows various linear regression tests.

The results show that greed have positive influence on the occurrence of corruption. Thus, $\mathrm{H} 1$ is accepted. We can see that the significance value of greedy 0.044 , smaller than 0.05 . The regression coefficient is 0.296 , which means that when greed increases one unit, corruption will increase by 0.296 . This result supports the statement that desire is one of the dominant factors influencing a person's behavior to become corrupt. This research results prove the effect of greed on cheating. [37] suggest that greed plays a very important role in human's behavior and cognition.

TABLE 4

\begin{tabular}{|l|l|l|}
\hline Mariables & Regression Coefficient & Sig._Value \\
\hline Constant & 1.543 & 0.693 \\
\hline Greed & 0.296 & 0.044 \\
\hline Opportunity & 0.390 & 0.047 \\
\hline Need & 0.053 & 0.708 \\
\hline Capability & 0.198 & 0.201 \\
\hline R & 0.787 & \\
\hline$R^{2}$ & 0.619 & \\
\hline
\end{tabular}

The results show that the opportunity has a positive effect on corruption. Thus, $\mathrm{H} 2$ is accepted. The results show a significant value of opportunity 0.047 , smaller than 0.05 . The regression coefficient is 0.390 , which means that when opportunity increases one unit, then the occurrence of corruption will increase 0.390. Our 
results support that opportunity encourages someone to commit fraud. It is happen because opportunity also related with governance, while bad corporate governance structure will increase the opportunity to corruption [37]. In Indonesia, the financial systems are still having much of weakness. It leads to rise much of fraud opportunity.

Our results show that need does not influence corruption. It can be seen significance value of need 0.708 is less than 0.05. Data processing results show that need does not influence corruption. Need is a "motivation" factors, which is the key reason of the improper behavior [37]. It is an internal factor that have big role to control individual behavior. But, in our case, the sample may have difference significant motivation besides need. [37] state that a need play role in accounting context, while our samples are come from difference background like public sector, government officials and not only from accounting or business context. This reason may explain why our results difference from the theory expectation.

The Capability also found that does not have any influence on corruption. It can be seen significance value of capability 0.201 is less than 0.05 . This results contras with previous studies. In Indonesia, the corruption punishment and the fraud management may still weak. The regulation not strong to deter corruption perpetrators. [12] state that the weaknesses in fraud detection mechanism and the role of fraud risk management lead to corporate failures. [37] state that the capability related to the possibility of fraud being discovered and disclosed and the level of punishment for cheating, which will deter potential cheaters. So, it did not support in Indonesia context that have limited regulation.

\section{Conclusions}

We examine the influence of greed, opportunity, need, and Capability on corruption. The results show that greed has a positive effect on corruption. It means that greed will provide to increase one's motivation to commit corruption. The opportunity affect positively corruption. The results show that the opportunity will provide an opportunity for someone to be able to corrupt easily. The variable need does not have a positive influence on corruption. The capability variable does not have a positive influence on corruption.

As for some suggestions generally from this research, such as the government is expected to implement a control and supervision system and manage a system of good governance that is clean to avoid corrupt behavior. Employees are expected to work with implement and comply with applicable regulations to prevent corrupt behavior. The community is expected to participate actively in providing supervision in government agencies in running duties and authorities. The role of society, both individually and as a group, is needed to answer this problem. Through social institutions, the community will exert deep influence formulation and public policymaking, which is a characteristic of a country's democracy, for example, by forming civic associations.

This research indeed cannot be separated from several limitations. The research data results indicate that there are still respondents who do not understand the question or statement instrument. A pilot test is needed to be related to the research questionnaire by involving academics and practitioners in refining the research questionnaire. Furthermore, the limitations of this study were only limited to the research location in A Padang prison. The study results cannot be concluded in general. It is necessary to research all prisons in Indonesia.

Future research can develop a model from this study, such as adding other variables or including mediation and moderation variables to examine the relationship to corrupt behavior. Further researchers can also test this research by maintaining the GONE Theory variable in influencing criminal behavior by analyzing data on the second-generation technique. Then, we can test this variable with a sample of prisons elsewhere to see the consistency of the results from previous studies. 


\section{References}

A. I. Luna-Pla and J. R. Nicolás-Carlock, "Corruption and complexity: a scientific framework for the analysis of corruption networks," Appl. Netw. Sci., vol. 5, no. 1, p. 13, 2020 .

B. J. Pinori, F. Langi, Ismiyarto, A. Johannes, and I. Setiawan, "Analysis of Government Apparatus Corruption Practice in Indonesia," Int. J. Psychosoc. Rehabil., vol. 24, pp. 5244-5252, Feb. 2020.

C. K. Casey and R. Bunker, "Facilitating Payments versus Bribes: Are We Sending Conflicting Ethical Signals in Accounting Education?," Int. J. Bus. Soc. Sci., vol. 3, pp. 47-50, Jan. 2012.

D. G. Follett, "Facilitation Payments: Facilitating Poverty?," Altern. Law J., vol. 40, no. 2, pp. 123-126, Jun. 2015.

E. A. Seleim and N. Bontis, "The relationship between culture and corruption: a cross-national study," J. Intellect. Cap., vol. 10, no. 1, pp. 165-184, Jan. 2009.

F. S. Fleming and M. McNamee, "The ethics of corporate governance in public sector organizations: Theory and audit," Public Manag. Rev., vol. 7, no. 1, pp. 135-144, 2005.

G. F. Zahra, M. I. Abdullah, A. Kahar, M. Din, and N. Nurfalah, "Preventing Procurement Fraud in E-purchasing for Indonesian Local Governments," J. Asian Financ. Econ. Bus., vol. 8, no. 2, pp. 505-511, 2021

H. J. Bologna, Handbook on Corporate Fraud. Boston: Butterwourth-Heinemman, 1993.

I. M. Tunley, "Need, greed or opportunity? An examination of who commits benefit fraud and why they do it," Secur. J., vol. 24, Nov. 2010.

J. E. M. Homer, "Testing the fraud triangle: a systematic review," J. Financ. Crime, vol. 27, no. 1, pp. 172-187, Jan. 2019.

K. M. F. Zimbelman, C. C. Albrecht, W. S. Albrecth, and C. O. Albrecth, Akuntansi Forensik (Forensic Accounting). 2014.

L. M. M. Marzuki, W. Z. N. A. Majid, N. K. Azis, R. Rosman, and N. K. H. Abdulatiff, "Fraud Risk Management Model: A Content Analysis Approach," J. Asian Financ. Econ. Bus., vol. 7, no. 10, pp. 717-728, 2020.

M. S. P. Huntington, Political order in changing societies. London: Yale University Press, 2006.

N. S. Schwartz, "Are There Universal Aspects in the Structure and Contents of Human Values?," J. Soc. Issues, vol. 50, pp. 19-45, Apr. 2010.

O. G. De Graaf and L. W. J. C. Huberts, "Portraying the Nature of Corruption Using an Explorative Case Study Design," Public Adm. Rev., vol. 68, no. 4, pp. 640-653, Jul. 2008.

P. S. Kotsiantis, E. Koumanakos, D. Tzelepis, and V. Tampakas, "Forecasting fraudulent financial statements using data mining," Int. J. Comput. Intell., vol. 3, pp. 104-110, Nov. 2005.

Q. E. Kirkos, C. Spathis, and Y. Manolopoulos, "Data Mining techniques for the detection of fraudulent financial statements," Expert Syst. Appl., vol. 32, no. 4, pp. 995-1003, 2007.

R. C. Spathis, M. Doumpos, and C. Zopounidis, "Detecting falsified financial statements: A comparative study using multicriteria analysis and multivariate statistical techniques," Eur. Account. Rev., vol. 11, pp. 509-535, Feb. 2002.

S. D. R. Cressey, Other people's money; a study of the social psychology of embezzlement. New York, NY, US: Free Press, 1953.

T. J. Dorminey, A. Fleming, M.-J. Kranacher, and R. Jr, "The Evolution of Fraud Theory," Issues 
Account. Educ., vol. 27, p. 555, May 2012.

U. C. Free, "Looking through the fraud triangle: a review and call for new directions," Meditari Account. Res., vol. 23, no. 2, pp. 175-196, Jan. 2015.

V. W. Huber, "Forensic Accounting, Fraud Theory, and the End of the Fraud Triangle," 2016.

W. D. Roden, "The Fraud Triangle as a Predictor of Corporate Fraud," Acad. Account. Financ. Stud. J., vol. 20, pp. 80-92, Jan. 2016.

X. O. Sorunke, "Personal Ethics and Fraudster Motivation: The Missing Link in Fraud Triangle and Fraud Diamond Theories," Int. J. Acad. Res. Bus. Soc. Sci., vol. 6, Mar. 2016.

Y. M. Sujeewa and I. Dharmaratne, "The New Fraud Triangle Theory - Integrating Ethical Values of Employees," Int. J. Business, Econ. Law, vol. 16, no. 5, Oct. 2018.

Z. G. L. Vousinas, "Advancing theory of fraud: the S.C.O.R.E. model," J. Financ. Crime, vol. 26, no. 1, pp. 372-381, Jan. 2019.

AA. I. Waluyo, The regional health insurance coverage incentive: a shift from opportunity to rationalization. 2020 .

BB. A. Schuchter and M. Levi, "The Fraud Triangle Revisited," Secur. J., vol. 29, pp. 107-121, Apr. 2016.

CC. M. E. Lokanan, "Challenges to the fraud triangle: Questions on its usefulness," Account. Forum, vol. 39, no. 3, pp. 201-224, 2015.

DD. R. Abdullahi and N. Mansor, "Concomitant Debacle of Fraud Incidences in the Nigeria Public Sector: Understanding the power of Fraud Triangle Theory," Int. J. Acad. Res. Bus. Soc. Sci., vol. 5, pp. 241-255, 2015.

EE. S. Dellaportas, "Conversations with inmate accountants: Motivation, opportunity and the fraud triangle," Account. Forum, vol. 37, no.
1, pp. 29-39, 2013.

FF. D. Wolfe and D. Hermanson, "The Fraud Diamond: Considering the Four Elements of Fraud," CPA J., vol. 74, pp. 38-42, Dec. 2004.

GG. J. Li, "False Financial Statement Identification Based on Fuzzy C-Means Algorithm," Complexity, vol. 2021, p. 5522894, 2021.

HH. R. G. Nijenhuis, "Prevention of Dutch fraud cases: a multiple case study on the effectiveness of internal control in the process of financial statement fraud prevention." 16-Jun-2016.

II. W. Peprah, Predictive Relationships among the Elements of the Fraud Diamond Theory: The Perspective of Accountants, vol. 8. 2018.

JJ. W. S. Albrecht, C. C. Albrecht, and C. O. Albrecht, "Fraud and Corporate Executives: Agency, Stewardship and Broken Trust," Journal of Forensic Accounting, vol. 5. pp. 109-130, 2004.

KK. W. Zou, "Analysis of Financial Fraud of Listed Company in China: A Case Study of Dandong Xintai Electric Co., Ltd.," Am. J. Ind. Bus. Manag., vol. 06, no. 09, pp. 931-941, 2016. 